\title{
SABER FAZER \\ IMPLICAÇÕES DA QUALIFICAÇÃO
}
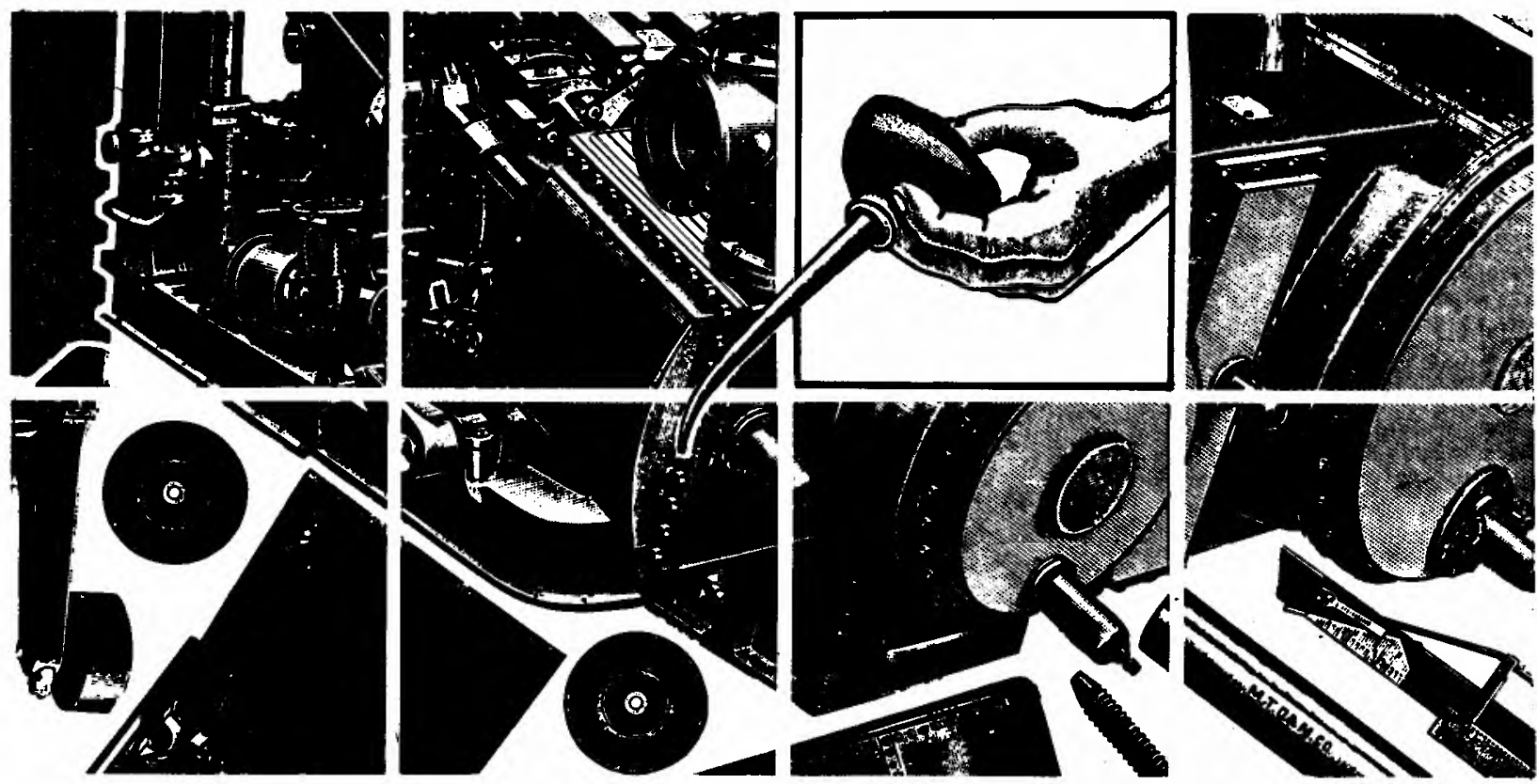

RESUMO: $O$ objetivo deste trabalho é discutir alguns aspectos envolvidos pelo conceito de qualificação aqui analisado a partir das relaçōes de trabalho concretas. Percebe-se uma ambigulidade entre a idéia de qualificação e a adoção de inovação tecnológica na indústria têxtil. Políticas patronais implicando alta rotatividade, baixos salários e baixa qualificação atuam como estratégia para dificultar a formação de uma categoria profissional e, conseqüentemente, reduzir o seu poder de barganha. No entanto, outros objetivos empresariais (como a qualidade do produto) poderão ño ser atendidos num regime de desqualificação generalizada do trabalhador coletivo.

PALAVRAS-CHAVE: Relaçōes de trabalho, qualificação, saber fazer, tecnologia.

- Helena Marla Tarchi Crivellari

Mestranda e Auxiliar de Pesquisa do Curso de Mestrado em Administraçăo da Universidade Federal de Minas Gerais e Universidade Federal da Bahia (CMAUFMG-UFBA).

\section{- Marlene Catarlna de Olvelra Melo}

Professora Adjunta e Pesquisadora do Curso de Mestrado en Administração/DCA da Universidade Federal de Minas Gerais (CMADCANFMG) e Doutora em Ciências das Organizaçōes pela Université Paris IX - Dauphine.

Este trabalho foi apresentado na XI Reuniáo Anual da ANPAD, Rio de Janeiro, 1987.

\section{INTRODUÇÃo}

"Quando eu entrei na indústria têxtil, era tear liso (semi-automático). A gente começava a aprender com outra tecelä, no acompanhamento, com duas máquinas. Tomava a maior surra. Era um tecelão para duas máquinas. Fazia tudo. Não tinha ajudante. A tecelä limpava a máquina, operava, varria o lugar que trabalhava. A gente varria com vassoura de capim, daquela artesanal, a gente pegava no mato para varrer debaixo das máquinas. Essa limpeza era feita de 4 em 4 horas. Aos sábados, pegava o serviço às 4 horas da manhã, para dar faxina geral. Passava até pano molhado em volta do seu 'circulo de trabalho'. As 6 horas (da manhã), ligava as máquinas. Esse mesmo tear foi aumentando, de uma pessoa para dois teares até uma para oito teares. E continuava também limpan- 
do etc. Nem aumentou salário. Começava a pegar às 4 horas da manhã $e$ ia até 10 horas do dia. Depois de 14 às 18 horas. O tear automático foi implantado há mais ou menos 20 anos atrás. É o mesmo tear que se usa até hoje. Com o tear automático, no principio, era uma pessoa para 10 teares. Depois passou para 12,16, eu fui até os 28 teares ( há 13 anos). Hoje são 50 por pessoa.

Antes o tear não tinha parada automática nem troca automática de lançadeira. São pequenos aparelhos que vão sendo introduzidos no tear principal $e$ possibilitam estas melhoras. A linha do urdume melhorou de qualidade. A qualidade da linha também facilita à tecelā operar mais máquinas. A limpeza: outras pessoas (que não a tecelä) passaram a fazer a limpeza das máquinas. A limpeza, desta forma, veio com o tear automático, é a limpeza através de ar comprimido. Uma pessoa vem com a mangueira, soprando a sujeira. Antes, era com estopa ou com escova. O barulho é o mesmo. Quanto maior a fábrica, mais tear, mais barulho... Deviam arrumar um jeito de acabar com o barulho..." (Operário do setor têxtil.)

É nesta situação de vivência profissional que pretendemos inserir algumas reflexões sobre qualificação. Também desta vivência vamos extrair alguns dados que permitam uma melhor compreensão do tema através da busca de uma noção de qualificação e suas implicações/ interações com relações de trabalho, tecnologia e saber tácito.

\section{A NOÇÃO DE QUALIFICAÇÃO}

Os estudos sobre qualificação têm suscitado interrogações sobre a evolução das qualificações, as mudanças que as afetam, a transformação das configuraçōes sociais do trabalho, as modificações nas formas de trabalho, as variações de emprego e da remuneração da força de trabalho, entre outras.

O maquinismo industrial é o resultado da divisão do trabalho que, por sua dialética interna, transformou profissões inteiras e tarefas complexas em tarefas múltiplas, parceladas, confiadas a indivíduos distintos, constituídas e regulamentadas pelos escritórios de métodos e com reflexos no campo econômico e técnico. J.D. Reynaud ${ }^{1}$ sintetiza bem efeitos desta divisão do trabalho, num primeiro momento de análise: tornar inúteis e supérfluos os principais elementos da qualificação, substituindo saber explícito, conhecimento intuitivo e habilidades, e confiando este saber aos escritórios de estudo que simplificam as tarefas e as subordinam à lógica desses próprios centros de concepção. A divisão do trabalho, na maioria das vezes, multiplica trabalhos monótonos, sem iniciativa e sem domínio, seja do equipamento ou do próprio produto.

O sistema de qualificação tem relação direta com um dado momento da divisão do trabalho. Sustentando tese, segundo a qual a organização social da temporalidade de aprendizagem seria determinada, em primeiro lugar, por uma necessidade intrinsecamente técnica da formação das competências, certos pesquisadores têm se interessado pelas perturbaçōes que a divisão do trabalho pode trazer à produção do saber fazer. suas inquietações dirigem-se ao empobrecimento do capital técnico coletivo que resulta, na maioria dos casos, na desqualificação e em efeitos sobre a identidade profissional.

Outros pesquisadores têm pretendido sublinhar o fato de que o parcelamento do trabalho não provoca necessariamente a degeneração do saber fazer, mas que há possibilidade de reconversão em direção a novas tarefas. Outros, ainda, têm tentado mostrar que a construção do conceito de qualificação requer o estudo simultâneo da formação social do valor de uso e do valor de troca da força de trabalho, sendo a qualificação a articulação entre os dois. Para Catherine Paradeise ${ }^{2}$, esta concepção da qualificação envolve disputas no campo do trabalho, onde se afrontam diversos grupos objetivando a construção de competências e a sua valorização nos postos de trabalho.

Esta amplitude no tratamento da qualificação mostra bem a complexidade do assunto, sendo necessário traçar algumas linhas diretrizes para a abordagem do tema. A qualificação do trabalhador está estreitamente ligada à transformação das tarefas. As mudanças relativas à qualificação sempre estiveram associadas a grandes tendências do maquinismo: passagem de máquinas universais a máquinas especializadas; no segundo momento, aos equipamentos automáticos $\mathrm{e}$, atualmente, à presença da microeletrônica.

George Friedmann ${ }^{3}$, analisando as transfor-

1. REYNAUD, J.D. "Qualification et marché du travail". In:Sociologie du travail. Paris, $\mathrm{n}^{2} 1,1987$.

2. PARADEISE, Catherine. "Des savoirs aux compétences: qualification et régulation des marchés du travail". In: Sociologie du travail. Paris, $\mathrm{n}^{2}$ 1, 1987.

3. FRIEDMANN, G. Problemes humains du machinisme industriel. Paris, Gallimard, 1950; e FRIEDMANN, G. Où va le travail humain? Paris, Gallimard, 1963. 


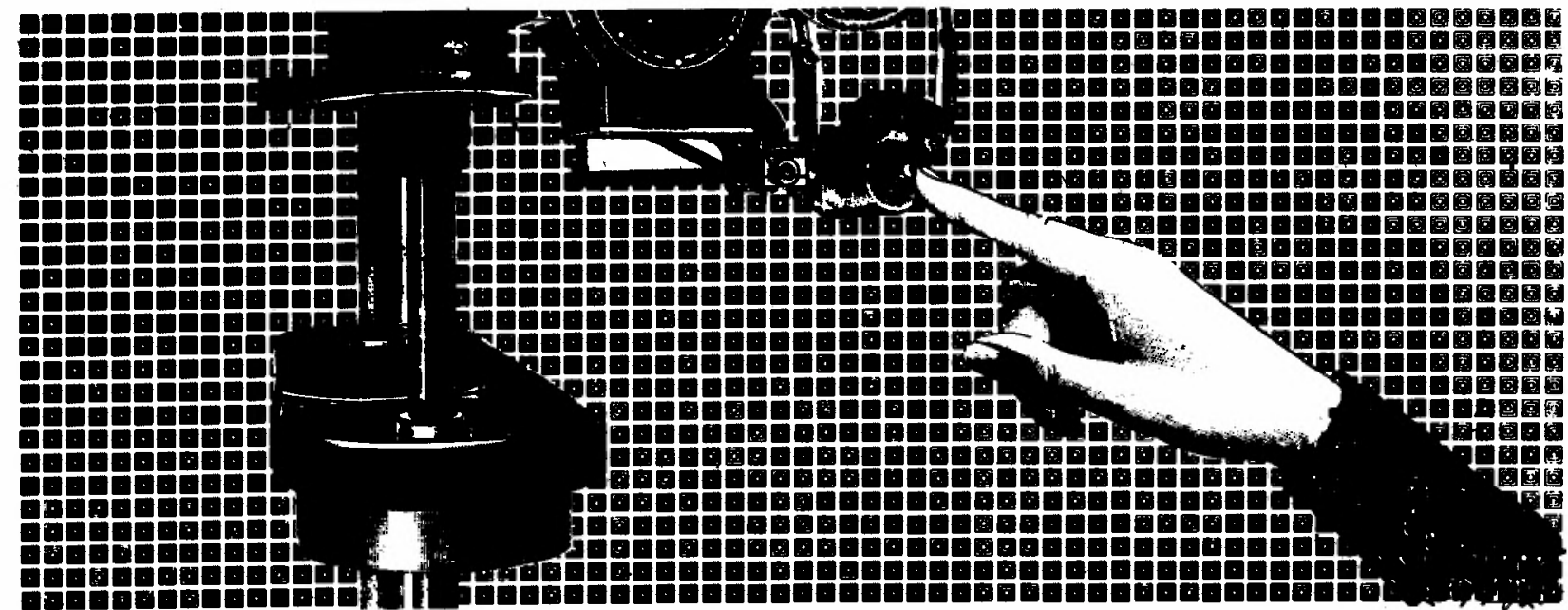

maçð̋es sociais de sua época, relativas ao trabalho humano, sistematiza as primeiras preocupaçס̃es relativas à organização do processo de trabalho e às inovaçōes tecnológicas. Os conhecimentos e o saber fazer, afirma o autor, não se relacionam mais à matéria, aos produtos, às habilidades, às astúcias, à vivência e à experiência na profissão como antes, mas somente ao funcionamento da máquina e ao ambiente de trabalho.

Sem nenhuma proposição de definição sistemática, $o$ autor trata qualificação remetendo-a a diversas realidades 4 : a habilidade profissional; aos conhecimentos profissionais ou técnicos; à inteligência profissional; às qualidades intelectuais; ao tato e à intuição profissional; à experiência técnica; ao "faro" e perspicácia profissionais; à aprendizagem feita durante anos; à aprendizagem metódica; ao domínio da máquina; à iniciativa no método de trabalho, na escolha dos instrumentos de trabalho, na duração e na velocidade da operação, aos conhecimentos da matéria-prima trabalhada, à consciência profissional, a um aspecto quase artesanal, ao companheirismo, as profissões antigas e tradicionais, às profissões unitárias, à cultura profissional.

Friedmann trata da desqualificação através da não-qualificação de forma sucinta e objetiva: uma mão-de-obra especializada(diferente de especialista, ou seja, não qualificada), executando um trabalho simples, parcelado e repetitivo, onde a iniciativa desaparece, a responsabilidade dilui, a "formação" sendo feita através da aprendizagem de algumas rotinas e em pouco tempo. Enfim o treinamento desta mão-de-obra constitui-se basicamente de gestos.

Ao realizarmos uma pesquisa em indústrias do setor têxtil de Minas Gerais sobre tecnologia e relações de trabalho não pretendíamos, de an- temão, tratar especificamente do tema qualificação. Percebemos, logo após as primeiras visitas e recolhidos os primeiros dados, que a inovação tecnológica adotada no setor, ao longo dos anos, tinha produzido uma mão-de-obra não qualificada bem nos moldes colocados por Friedmann. Estudos como os de Neves ${ }^{5}$, Schmitz ${ }^{6}$ e Carvalho ${ }^{7}$ mostram como a tecnologia condicionou possibilidades de políticas de gestão da mão-deobra adotadas pelas empresas especialmente quanto ao uso de trabalhadores pouco qualificados, intensificação da mão-de-obra feminina e prática da rotatividade elevada.

A redução do emprego ocorreu em termos absolutos para o setor como um todo. Em 1950, a indústria têxtil empregava 264.606 trabalhadores, na produção de um valor adicionado aproximado de 4 bilhões de cruzeiros (a preço de 1975). Em 1975, 209.857 pessoas trabalhavam para produzir um valor adicionado de mais de

4. FRIEDMANN, G. Problemes humains du machinisme industriel. Op. cit.

5. NEVES, M.A. Condição Feminina - condição operária: um estudo de caso sobre operárias têxteis. Belo Horizonte, tese de mestrado apresentada ao Departamento de Ciências Políticas da Universidade Federal de Minas Gerais (DCP/UFMG), 1983.

6. SCHMITZ, H.A. "A Microeletrônica: suas implicaçōes sobre o emprego e o salário". In: Pesquisa e Planejamento Econômico. Rio de Janeiro, IPEA, vol.15, $\mathrm{n}^{\mathrm{Q}}$ 3, dezembro, 1985, pp.639-680; e SCHMITZ, H.A.Technology and employment practices in developing countries. Londres, Croom Helm, 1985 apud CARVALHO, Ruy Q. Tecnologia e trabalho industrial: as implicaçōes sociais da automaçāo microeletrónica na industria automobilística. Porto Alegre, L\&PM, 1987.

7. CARVALHO, Ruy Q. Op. cit. 
10 bilhões de cruzeiros ${ }^{8}$.

Schmitz analisou efeitos da mudança tecnológica na natureza do trabalho. Comparando a descrição de cargos de 1950 a 1980 de operadores de máquina de fiar e operadores de tear (trata-se de duas categorias-chave para o setor), notou que as tarefas mais complexas que envolviam manipulação coordenada e resolução de problemas foram significativamente reduzidas. Conseqüentemente, a redução do tempo de treinamento necessário para um operário atingir a produtividade média nas duas categorias (comparando os períodos de 1950 e 1980) confirma a tendência à desqualificação. Acero ${ }^{9}$ enfatiza a desqualificação do trabalhador coletivo. Tendo a tecnologia eliminado algumas tarefas e simplificado outras, algumas ocupações especiais, cujo trabalho levava anos para ser aprendido e que detinham um poder decisório na produção que afetava os demais trabalhadores, foram completamente eliminadas ${ }^{10}$.

A introdução das inovações tecnológicas nas fases básicas de produção na indústria têxtil (fiação, tecelagem e acabamento) não tem ocorrido de forma homogênea. Mas as possibilidades de uso de equipamentos automatizados de base microeletrônica são grandes. A etapa de acabamento é a de maior potencial para a difusão da automação. No entanto, na tecelagem ${ }^{11}$, microprocessadores podem ser acoplados nos compensadores de velocidade e nos controles em geral de teares de várias espécies, de forma a otimizar o ritmo de produção(número de batidas/minuto) e especificação do tecido (número de inserções $/ \mathrm{m}^{2}$ ). Nesta etapa, tem havido um grande dinamismo tecnológico no aperfeiçoamento dos teares, com características específicas para cada tipo (sem lançadeira, a pinça, a projétil, a jato de água e a jato de ar), já sendo possível controlar totalmente a operação da sala de tecelagem por um único operador através de controles eletrônicos integrados.

$\mathrm{Na}$ verdade, se as estruturas produtivas do setor têxtil tendem a ser atualizadas, esta inovação tecnológica no Brasil tem se dado de forma mais lenta em relação aos padrões tecnológicos internacionais e, ainda, de forma diferenciada. No entanto, a inovação tecnológica, mesmo em níveis gradativos, acarreta novas concepções do setor produtivo e da estrutura organizacional e ocupacional.

O desenvolvimento da pesquisa em indústrias têxteis, visando à análise da tecnologia e das relações do trabalho, permitiu-nos definir operacionalmente relações de trabalho como sendo aquelas que se estabelecem na e para a realização do processo de trabalho, incluindo, então, a divisão e a organização do trabalho, a gerência da força de trabalho, as condições de trabalho e o processo de regulação de conflitos inerentes à estrutura social de produção. Assim, a variável qualificação passou a ser relevante em todas as dimensões consideradas no conceito de relações de trabalho. Percebemos, também de início, que qualificação não se prendia apenas à análise do qualificar/desqualificar, ou qualificado/não qualificado. Existem múltiplas facetas que se completam e que possibilitam novas leituras sobre o tema. Vejamos algumas delas:

a) A situação dominante da divisão e da organização do processo de trabalho tem conduzido o estudo da qualificação, na sua maior parte, para a qualificação operária. No entanto, com as recentes evoluções da tecnologia, principalmente com o avanço da microeletrônica, outras categorias profissionais, como pessoal administrativo, técnicos e mesmo gerentes, têm sido afetadas e inseridas no contexto das qualificações/ desqualificações.

b) É difícil distinguir a qualificação de um indivíduo da qualificação do posto de trabalho. No final das contas, a verdadeira qualificação é aquela do posto de trabalho em questão, porque é o posto de trabalho que comanda a demanda de certo tipo de trabalho ${ }^{12}$.

c) A qualificação como capital que um indivíduo detém e que ele procura fazer valer no mercado de trabalho tem possibilidades diferentes segundo a raridade/quantidade desta qualificação e a necessidade que se faz dela.

d)Em muitos casos, interrogações que dizem respeito às estatísticas referentes às categorias sócio-profissionais e o efeito direto das tecnologias não levam em consideração o fato de, mesmo que a qualificação esteja estreitamente ligada a um estado da técnica ${ }^{13}$, a organização poder fazer escolhas e que nestas escolhas estão embu-

8. SCHMITZ, H.A. Technology and employment practices in developing countries. Op. cit.

9. ACERO,L."Technical change in a newly industrializing country: a case study of the impacts on employment and skills in the brazilian textiles industry, SPRU".In: Occasional Paper Series. Brighton, $\mathrm{n}^{2} 22$, SPRU/University of Sussex, 1984 apud CARVALHO, Ruy Q. Op. cit.

10. Idem, ibidem, pp.54-55.

11.TAUILLE, J.R. "Automação e competitividade: uma avaliação das tendências no Brasil". In: Texto para discussão. IEl/UFRJ, nº 111, 1987.

12. REYNAUD,J.D.Op.cit.

13. Não se pode,obviamente, desconsiderar as análises exaustivas das conseqüências do Taylorismo e mesmo do Fordismo. 
tidos determinantes sociais.

As razőes pelas quais uma certa capacidade/ competência profissional ou atitude sejam valorizadas na qualificação ainda são mal definidas. A sua raridade no mercado de trabalho, naturalmente, valoriza-as. Mas há que se considerar que os métodos de avaliação das tarefas e cargos que definem a classificação são apoiados em um conjunto de critérios que seguem uma determinada lógica de reprodução e manutenção de uma estrutura de poder.

Reynaud ${ }^{14}$ lembra também a necessidade de se levar em conta a inserção da aprendizagem das relações de colaboração e de subordinação na busca de se apreender a noção de qualificação. Tal aprendizagem se relaciona a uma certa repartição implícita das responsabilidades e das iniciativas, aprendidas nas relações de famílias e de vizinhanças, além daquelas do próprio sistema escolar. Esta aprendizagem constitui-se numa qualificação, facilitando a assimilação de ordens e normas precisas sobre condutas a se ter no local de trabalho, além de dar orientações para o comportamento em situações não previstas. Em síntese, observa-se que ao saber fazer soma-se um saber viver. Na prática, esta capacidade tem sido reconhecida pelo empregador no processo de seleção e na decisão do admitido.

Sabe-se que este tipo de socialização pode ser feita depois do ingresso na organização. Mas, de fato, esta disposição social (ou conformismo às relações sociais estabelecidas e reproduzidas pelos diversos aparelhos ideológicos, em níveis diferentes) ${ }^{15}$ constitui-se, em geral, numa exigência de trabalho e ela passa a significar qualificação. Um dos motivos é que ela facilita a convivência não só com a cultura da empresa ${ }^{16}$ mas também com a cultura da categoria, da profissão, do grupo de trabalho, na medida em que ela limita ou estende as possibilidades de comunicação, de troca, de colaboração, de decisão, de controle.

O aproveitamento de membros da família ou das redondezas da fábrica e de localidades onde se concentra uma certa categoria funcional, como é o caso da indústria têxtil, atesta que a qualificação compreende também o chamado saber viver em sociedade, segundo padrões e normas próprias de um determinado espaço de trabalho ou categoria profissional.

Uma outra face da noção de qualificação é a análise do nível da possibilidade de substituição do trabalhador. Mesmo quando um indivíduo não é qualificado (cada um sendo facilmente substituível), o conjunto que eles constituem possui uma qualificação apreciável, trazendo dificuldades para uma possível substituição do conjunto.

No local de trabalho existem hábitos, tradições, certas regras não escritas, experiência acumulada que permitem resolver imprevistos, certa facilidade de comunicação pela posse de um código comum, controles informais, enfim, um conjunto de "coisas" que possibilitam e mantêm de fato o funcionamento oficial de uma organização. Além deste espaço cultural e simbólico, enfim do cotidiano, a aprendizagem da tarefa, no local de trabalho, assegura a formação do coletivo profissional e, ainda, um certo controle do grupo sobre a transmissão de conhecimentos e o fluxo dos recém-chegados. Esta coalisão tem um papel, mesmo que restrito, de criar certas características do mercado interno, apoiando ou dificultando a inclusão de novos membros, o que reforça a identidade coletiva, pois aquilo que se transmite ao "aprendiz" no treinamento da tarefa não trata apenas do conhecimento, do saber fazer, mas, também, de conviç̧ões, obrigações, macetes, representações comuns, normas, comportamento e restrições do grupo. Neste sentido, a qualificação aparece como uma construção de um ator social coletivo complexo que, ao mesmo tempo, defende um capital econômico no âmbito do mercado de trabalho e um capital simbólico de recursos normativos e de sobrevivência.

$\hat{E}$ neste espaço que se inserem os conhecimentos adquiridos através da experiência individual e prática do trabalhador e que dificilmente são passíveis de explicitação formal ou codificação, ou seja, o saber tácito. O saber tácito refere-se à capacidade de apreensão e identificação - pela vivência - dos estados de normalidade ou anormalidade do processo de produção, a partir das condições do próprio ambiente de trabalho.

Assim, qualquer que seja a "face" da qualificação, trata-se de uma análise difícil, pois a relação entre elementos heterogêneos que a compõem não permite uma correspondência

14. REYNAUD,J.D.Op. cit.

15.ALTHUSSER,L.Posições 2. Rio de Janeiro, Graal, 1980, pp.47-101.

16. Cultura de empresa, de acordo com Júlio Lobos - "Stress e 'Cultura da Empresa': especialista rejeita conceitos". In: Tendências do Trabalho. Rio de Janeiro, junho, 1986, pp.12-13 - , pode significar usos, valores e costumes funcionais, servindo a interesses específicos (interesses gerenciais e daí para cima), fornecendo um "guarda-chuva" aos atos do grupo dominante. Assim, acertos e realizações, bem como injustiças e aberrações passam a ser explicados pela cultura organizacional que é construída e aprimorada intencionalmente. 
nem clara, nem imediata, nem harmoniosa. Claude Dubar ${ }^{17}$ propõe características essenciais na operação de análise da qualificação através do tipo de articulação privilegiado e do campo no qual esta operação se efetua. Ele distingue cinco abordagens da qualificação, configurando um polígono formado pelos seguintes ângulos temáticos:

a) articulação/confrontação entre qualificação dos postos de trabalho e qualificação dos trabaIhadores no interior de sistemas de trabalho;

b) articulação/combinação entre qualidades pessoais subjetivas e conhecimentos reconhecidos e objetivados no seio de sistemas profissionais;

c) articulação/relação entre trajetórias biográficas e sistema de emprego num processo de socializaçăo (carreira);

d) articulação/negociação entre valor de uso e valor de troca da força de trabalho no campo das relações profissionais (mercado de trabalho);

e) articulação/construção de relações entre o espaço educacional, organizacional e industrial dentro de um sistema societal.

Qualificação, portanto, é um conceito dinâmico, multifacetado e que se situa em "n" pontos da área deste polígono teórico. No entanto, "sem nenhum determinismo estrito, as formas de organização de trabalho, dos sistemas de qualificação, das classificações ou dos niveis de promoção são inteiramente dependentes das relações de força $e$ dos compromissos que podem ser estabelecidos entre os grupos de interesse" 18.

\section{QUALIFICAÇÃO E RELAÇŐES DE TRABALHO}

O campo das relações de trabalho configura-se como o locus privilegiado de manifestação das relações de poder, assumindo formas diversas de expressão conforme as relações de força existentes entre os grupos de interesse na sociedade e na própria empresa.

Estando as relações de trabalho regidas pelas relações de poder entre os grupos de interesse no âmbito da organização, a mobilização dos trabalhadores determina parcelas significativas de como acontecem, na prática, os vários momentos das relações de trabalho. Verifica-se que as relações entre empregado(s) e empregador(es) se traduzem por uma lógica dupla, permanente e contraditória de afrontamento, negociação ou acomodação/aceitação. Vejamos, então, alguns pontos do campo das relações de trabalho nas três indústrias têxteis pesquisadas ${ }^{19}$.

O processo tecnológico determina um siste- ma de qualificação correspondendo a um tipo de organização da produção, mas, também, a uma organização da empresa (definição de funções e postos de trabalho, entre outros), o que quer dizer um determinado estado da divisão do trabalho, da coordenação, da gerência e do exercício do controle.

Segundo os operários entrevistados, o controle das pausas é feito pelo próprio operário (56\%) e por meios externos ( $44 \%$ ), enquanto que os processos mais usuais para disciplinar são: o controle rígido pelo encarregado, o controle operário-operário, ameaça, livro de anotações e normas da empresa, advertência escrita, monitor e a demissão. (Ver quadro 1.)

\section{QUADRO 1}

\begin{tabular}{|l|c|c|}
\hline $\begin{array}{l}\text { Processos Utilizados para } \\
\text { Disciplinar os Empregados }\end{array}$ & $\begin{array}{r}\text { Freqüếncia } \\
\text { Absoluta }\end{array}$ & $\begin{array}{c}\text { Freqüência } \\
\text { Relativa \% }\end{array}$ \\
\hline $\begin{array}{l}\text { Controle rígido pelo } \\
\text { encarregado }\end{array}$ & 34 & 29,0 \\
\hline Controle operário-operário & 18 & 15,0 \\
\hline Ameaça & 18 & 15,0 \\
\hline $\begin{array}{l}\text { Livro de anotaçōes e } \\
\text { normas da empresa }\end{array}$ & 18 & 15,0 \\
\hline Advertência escrita & 12 & 10,0 \\
\hline Monitor & 10 & 8,0 \\
\hline Demissão & 10 & 8,0 \\
\hline
\end{tabular}

FONTE: Operários entrevistados.

Ainda neste espaço do controle, é interessante notar a interdependência dos operários na execução das tarefas, o que reforça o controle operário-operário no interior da fábrica têxtil. Dos entrevistados, $76 \%$ afirmaram depender de outro colega para execução da tarefa e $68 \%$, que outros dependem dele(ver quadro 2). Segundo os entrevistados, o controle do volume da produção é feito por mecanismo controlador (53\%), e/ou pelo encarregado ( $28 \%$ ), e/ou por outro empregado $(28 \%)$, e pelo próprio operador $(24 \%)$.

Cada sistema produtivo coloca um problema particular de organização e recebe uma solução

17. DUBAR, Claude. "La qualification à travers les journées de Nantes". In: Sociologie du travail. Paris, $n^{2} 1,1987$.

18. CORIAT, Benjamin. "Autônomos, robôs e a classe operária". In: Novos Estudos CEBRAP. São Paulo, CEBRAP, vol. 2, $\mathrm{n}^{\mathrm{2}} 2,1983$, p.38.

19. A pesquísa foi realizada em três empresas têxteis de Minas Gerais - foram entrevistados 39 operários , 33 gerentes, 8 engenheiros e 7 sindicalistas. 


\section{QUADRO 2}

\begin{tabular}{|l|c|c|}
\hline $\begin{array}{l}\text { Relaçбes de Dependência } \\
\text { No Trabalho Operário }\end{array}$ & $\begin{array}{c}\text { Frequêencia } \\
\text { Absoluta }\end{array}$ & $\begin{array}{c}\text { Freqüência } \\
\text { Relativa \% }\end{array}$ \\
\hline $\begin{array}{l}\text { Entrevistado depende de } \\
\text { ontrem }\end{array}$ & 76 & 40,0 \\
\hline $\begin{array}{l}\text { Entrevistado não depende } \\
\text { de outrem }\end{array}$ & 22 & 12,0 \\
\hline $\begin{array}{l}\text { Outros dependem do } \\
\text { entrevistado }\end{array}$ & 68 & 36,0 \\
\hline $\begin{array}{l}\text { Ninguém dependo do } \\
\text { entrevistado }\end{array}$ & 22 & 12,0 \\
\hline
\end{tabular}

FONTE: Operários entrevistados.

mais ou menos singular. A definição de um posto de trabalho é a cada vez uma invenção, tornando-se este fato mais evidente à medida que se trata de um posto de trabalho novo ou de maior qualificação. Nesse processo, colocam-se as diferenças de níveis de formação, a demanda desta formação no mercado de trabalho e a disponibilidade de oferta, os problemas e interesses da empresa relativos à organização, ou seja, aqueles de coordenação e de controle. As soluções podem ser variadas, mas repetem-se "famílias" de soluções que guardam traços genéricos, o que permite uma certa aceitação/ consenso produzidos entre a organização profissional e a organização hierárquica.

A organização profissional e o conseqüente status da qualificação expressam-se pelo prestígio, pelo posicionamento hierárquico $\mathrm{e}$, principalmente, pelo salário. Assim, a diferença entre uma categoria profissional e outra passa pelas capacidades profissionais possuídas pelo indivíduo, valorizadas pelo empregador através do nível de autoridade que o indivíduo exerce, a confiança que lhe é atribuída e pela dignidade(status) que lhe é conferida. Essas características compõem parte do poder de barganha e das relações de força entre os grupos de interesses (entre as categorias, e entre as categorias e o empregado).

O tecelão representa bem essa situação. A categoria tecelão tem passado por mutações ao longo dos anos e das inovações tecnológicas. $\mathrm{Na}$ primeira metade do século, grandes mobilizações operárias foram sustentadas pela categoria dos tecelões mais do que pelo empregado da indústria têxtil em geral. Ao lado do processo de industrialização do país, foram desenvolvidas formas de controle e repressão do movimento sindical a partir de 1964. Também, a partir de 1950, acelerou-se a absorção de inovações eletromecânicas no setor. Destaca-se a difusão do tear automático a partir da década de 50, e do tear sem lançadeira depois da década de 70. A modernização do setor têxtil intensificou o trabalho do operário tecelão e transformou-o cada vez mais num controlador/operador de máquinas.

Na nossa pesquisa, poucas vezes foi feita a referência direta ao tecelão enquanto categoria profissional. Percebe-se, então, que a cada etapa da adoção de inovações tecnológicas vem sendo criada a categoria "operador de máquinas", cargo comum a indústrias de setores variados, em detrimento da profissão tecelão. $O$ discurso do "tecelão" mostra bem sua nova situação profissional. Vejamos alguns extratos:

"O ano inteiro é a mesma coisa. Podia variar se tivesse outro tipo de máquina."(Tecelão)

"Não tenho mais nada pära aprender; o que aprendi fica só nisso mesmo. Meu estudo é pouco, entrei, aprendi a operar a máquina, e pronto. Estou nisso há 10 anos, não tenho vontade de aprender mais nada". (Tecelão)

"O serviço é muito mecânico, não depende de inteligência, nem do raciocínio. Só aprender $e$ fazer". (Tecelã)

O resultado da prática das empresas decorrente das inovações tecnológicas é o esfacelamento de uma profissão tradicional, conduzindo-a a uma outra categoria profissional. As referências profissionais para esses trabalhadores são novas, e a identidade de classe ou de categoria, ainda não formada, apresenta muitas incertezas quanto à sua relação de força e ao seu poder de barganha. Não seria esta uma das explicações a se somar às outras, já bem conhecidas, de um certo imobilismo desta categoria no conjunto das atuais pressões e greves dos trabalhadores brasileiros?

A desqualificação ou redução dos saberes exigidos para um determinado trabalho acabam por reduzir o poder de barganha do trabalhador que passa a ser substituído facilmente. $O$ sindicato dos empregados da indústria têxtil tem tido nas últimas décadas pouca expressão e força, acrescentando a esta baixa relação de força um excedente de oferta de mão-de-obra pouco qualificada, o que facilita as estratégias de desqualificação. Por outro lado, as novas tecnologias adotaḍas vêm favorecendo a utilização dessas estratégias pelas empresas.

O processo de treinamento no setor têxtil colabora com uma visão do conjunto da qualificação/desqualificação do trabalhador. Um operário do setor de acabamento, com dez (10) anos de fábrica, faz o seguinte comentário sobre o seu aprendizado para operar o alvejamento contínuo: "Não senti dificuldade no aprendizado. Com três (3) dias praticando, já aprendi." (Operador de Alvejamento Contínuo) Um ge- 
rente de produção completa o quadro dessa prática. "Apesar de não se encontrar, muito fácil, mão-de-obra qualificada, os trabalhadores daqui são plenamente substituíveis. A firma está evoluindo. Temos uma política sistemática de treinamentos. Pegamos mão-de-obra não qualificada no mercado e treinamos aqui. $\mathrm{Na}$ queles postos mais qualificados, sempre tem um ajudante potencialmente 'qualificado' para substituir o operador a qualquer momento."

A gerência da força de trabalho no setor têxtil dá importância à disciplina e à execução das tarefas a serem feitas, precisamente de acordo com as instruções. Schmitz ${ }^{20}$ afirma que esta política só se torna viável porque a tecnologia moderna e os métodos atuais de organização do trabalho reduzem em grau considerável as exigências de treinamento de mão-de-obra ${ }^{21}$. Para que esta política funcione é preciso cuidar dos procedimentos de seleção e formação de pessoal.

As empresas pesquisadas têm feito grande uso de mão-de-obra aprendiz. Trata-se de uma força de trabalho menos dispendiosa e rapidamente adaptada ao ritmo da produção. $O$ importante, no entanto, é que, com a diminuição das exigências de qualificaçăo, os custos de treinamento são compensados pelo que se ganha em termos de disciplina e controle sobre a força de trabalho.

Segundo informações obtidas pela pesquisa, "o setor de pessoal se relaciona com a produção, basicamente através do menor aprendiz, formado pelo SENAI, mediante convênio com a empresa. Na fábrica, eles recebem aula de português, matemática e conhecimentos gerais (no nivel das quatro primeiras séries do $1^{g}$ grau). $O$ chefe de pessoal é o próprio professor e coordenador do curso. A fábrica tem retorno com este curso. O menor aprendiz entra na fábrica como varredor. Com menos de cinco meses de trabalho, já está ligado à produção. O curso (8 horas) aula por mês) dura dois anos e a maioria é aproveitada depois. A idade minima para ingresso é 14 anos, a máxima 16 incompletos. Eles ganham $50 \%$ de remuneração básica ao entrar, após dois anos, passam a $2 / 3 \mathrm{e}$, com 18 anos, ganham salário mínimo." (Agente de Pessoal)

"O SENAI orienta e apura a programação. Na fábrica, eles aprendem a tecnologia com o chefe de seção e com o contramestre. $O$ controle da frequiência é feito pelo contramestre (só no caso do menor). Quando o chefe acha que a menina pode ser uma fiandeira, encaminha-a para lá; se tem aptidão para outros serviços, é também aproveitada." (Agente de Pessoal)

"Também se mostra ao aprendiz o que deve ser feito para evitar que se acidente, e estrague a máquina. Mostra o que vai fazer. O SENAI trata mais da parte teórica. Depois que o encarregado faz as preliminares, entrega o principiante para uma operária por 30 dias para completar o treinamento." (Supervisor)

"A maior parte são mulheres. Começam com 14 anos, entram como aprendizes. Freqüentam as aulas teóricas do SENAI durante dois anos: noçāo de como lidar com as máquinas, parte de higiene, comportamento no trabalho, uma hora por semana, geralmente na sexta-feira, depois do trabalho. Hoje, são mais ou menos 80 aprendizes. Meninos também entram com 14 anos. Menina vai ser fiandeira ou tecelä, e o menino, mecânico de manutenção." (Supervisor)

A prática de gestão da força de trabalho na indústria têxtil mostra uma política de rotatividade constante, intensificação do uso da mãode-obra feminina e a manutenção de salários baixos. Schmitz considera que quaisquer expectativas de que a modernização tecnológica possa resolver rapidamente $o$ problema do trabalho mal remunerado e em condiçôes instáveis devem ser deixadas de lado, e acrescenta que o fato crucial é que o aumento de tecnologia moderna tende a tornar mais fácil a substituição de um trabalhador por outro 22.

Ao tabularmos os dados referentes aos principais fatores geradores de conflitos/problemas apontados pelos operários entrevistados (veja quadro 3), vários temas levantados na busca de se caracterizar o espaço das relações de trabalho e qualificação na indústria têxtil foram realçados: do salário $(24 \%)$, passando pelo relacionamento com as chefias (24\%), que expõem o problema do controle, chegando-se à discriminação da mulher (2\%).

Em relação à mulher é interessante notar que o empregador reconhece facilmente certas qualidades consideradas como próprias à mão-deobra feminina tais como precisão do trabalho, minúcia, cuidado, habilidade manual, regularidade etc. Essas "qualidades" não constituem uma qualificação ${ }^{23}$. Essas "qualidades" não trazem aquelas que as possuem nem melhor classificação, nem remuneração mais favorável, mas elas são exigidas e apreciadas. A qualificação, no primeiro momento, não aprecia esses méritos, ela mede, antes de tudo, a relação entre oferta e

20. SCHMITZ, H.A. "A Microeletrônica: suas implicaçð̃es sobre o emprego e o salário". Op. cit.

21. Idem, ibidem, p.644.

22. Idem, ibidem.

23. REYNAUD, J. D. Op. cit 
demanda. Se a oferta dessas qualidades é abundante (ou mesmo superabundante), naturalmente o preço será baixo. Reynaud ${ }^{24}$ coloca objetivamente a questão das qualidades femininas no contexto das relaçð̃es de trabalho: essas qualidades emprestadas às mulheres não seriam a tradução imaginada de sua situação no mercado? Se essa mão-de-obra é cuidadosa, conscienciosa, disciplinada, não é simplesmente porque ela é dócil, ou mais precisamente dependente? Não seria ainda porque, em se tratando de uma reserva sempre disponivel, ela sofre, sem muitos meios de se defender, as restriçőes impostas pelo empregador? A referência à vida doméstica não indica, mais do que uma capacidade, um hábito de subordinação que se encontra, de forma bastante semelhante, no mercado de trabalho? ${ }^{25}$

\section{QUADRO 3}

\begin{tabular}{|c|c|c|}
\hline $\begin{array}{l}\text { Principais Fatores Geradores } \\
\text { de Conflitos/Problemas }\end{array}$ & $\begin{array}{l}\text { Frequência } \\
\text { Absoluta }\end{array}$ & $\begin{array}{l}\text { Frequência } \\
\text { Relativa \% }\end{array}$ \\
\hline Salário & 30 & 24,0 \\
\hline $\begin{array}{l}\text { Relacionamento com } \\
\text { as chelias }\end{array}$ & 30 & 24,0 \\
\hline Horário de trabalho & 11 & 9,0 \\
\hline Horas-extras obrigalórias & 8 & 7,0 \\
\hline $\begin{array}{l}\text { Desconforto do equipamento } \\
\text { de seguranca }\end{array}$ & 8 & 7,0 \\
\hline $\begin{array}{l}\text { Falta de refeitório e subsidio } \\
\text { para alimentação }\end{array}$ & 8 & $7,0<$ \\
\hline Absenteísmo & 5 & 4,0 \\
\hline Equipamentos de produçäo & 5 & 4,0 \\
\hline Nảo há conflitos/problema & 5 & 4,0 \\
\hline Condiçoes de trabalho & 5 & 4,0 \\
\hline $\begin{array}{l}\text { Prática do controle } \\
\text { de produção }\end{array}$ & 3 & 2,0 \\
\hline Assistência médica existenle & 3 & 2,0 \\
\hline Discriminaçāo da mulher & 3 & 2,0 \\
\hline
\end{tabular}

FONTE: Operários entrevistados.

Esta situação pode ser sintetizada pelos extratos de entrevistas de uma operária que nos informa sobre as condições de trabalho para a mulher na indústria têxtil: "ninguém procura o seu direito (...). Tem medo 'deles' achar ruim (...). O pessoal não acredita na lei que lhe respalda. Tem medo de perder o emprego (...). No SENAI, há discriminação. Não há serviços para mulher. Os cursos são para homens. No jornal da fábrica diz: $O$ que precisa para ser mecânico - ser homem, alto, grau de estudo etc. Não há chance para a mulher. Tem mulher com mais de 30 anos de casa sem cargo de chefia". (Operária de Fiação)

Finalmente, a qualificação não exprime so- mente, a um certo momento, as exigências de um posto de trabalho; ela é, na verdade, uma situação mais complexa. Ela também está interligada a uma sucessão de postos de trabalho, a uma certa trajetória profissional. Reconhecer uma qualificação a um assalariado é também atribuir-lhe uma certa confiança que vai além da execução estrita de um contrato de trabalho: buscar um certo engajamento para o futuro. No entanto, essa não tem sido a prática usual das empresas pesquisadas no que diz respeito ao pessoal de produção. Outros pontos referentes a esta situação serão apresentados a seguir, ao se tratar da qualificação e inovação tecnológica.

\section{QUALIFICAÇÃO E TECNOLOGIA}

Historicamente, a chegada das máquinas, como meio de produção, muda radicalmente o conceito de qualificaçăo.

A manufatura criou os meios para que a qualificação deixasse de ser algo próprio do trabalhador/individuo e assumisse um caráter de coletividade, ou qualificação social. E na medida em que o produto passou a ser resultado das operações da máquina, foi cabendo ao operário a execução da mesma e única tarefa rotineira, fácil de ser decodificada, transmitida a outros trabalhadores e reproduzida de maneira bastante igual. A soma destes trabalhadores, em sistema de rotina; dá-se o nome de trabalhador coletivo; e à soma de seus conhecimentos e habilidades, qualificação social.

Há, portanto, um encadeamento de saberes parciais, complementares e predeterminados em função de um resultado que excede a todos. Esta idéia é importante, na medida em que o encadeamento de saberes pode ser alterado, a depender da tecnologia e da política de gestão da força de trabalho adotadas. Assim, a distribuição dos postos de trabalho, o conteúdo das funções e, conseqüentemente, a qualificação para estes postos e/ou funçōes estão relacionados à tecnologia e à gestão da mão-de-obra.

Naturalmente, a concentração ou desconcentração de atribuições acaba gerando um movimento de desqualificação ou superqualificação da força de trabalho, que vem afetar o valor de uso e o valor de troca da mão-de-obra.

24. Idem, ibidem.

25. Idem, ibidem, p.93. 
No que tange à indústria têxtil mineira ${ }^{26}$, os equipamentos são convencionais e prevalecem as máquinas que subordinam o trabalhador. Embora as fábricas tenham sido alvo de inovações tecnológicas, durante os últimos dez anos, ainda não houve a implementação de equipamentos mais sofisticados, baseados em tecnologia microeletrônica. Os antigos teares mecânicos foram substituídos pelos automáticos - mas não há ainda instalados, nestas fábricas, os teares "sem lançadeira". A grande inovação ocorreu na área de preparação para a fiação e na área de acabamento, passando de sistemas manuais para equipamentos de fluxo contínuo.

Do ponto de vista do trabalhador, comparações feitas por Schmitz ${ }^{27}$ entre empresas têxteis diversas revelaram não ser muito vantajoso trabalhar numa fábrica com tecnologia mais avançada. O trabalho é muito repetitivo e cansativo (as tecnologias adotadas são, geralmente, importadas de países centrais onde prevalecem melhores condições de trabalho - jornadas reduzidas, por exemplo - o que implica, para os trabalhadores do país importador, uma carga mais intensa de trabalho, traduzida, no mínimo, por um ritmo igual em uma jornada de trabalho mais longa) ${ }^{28}$. Schmitz acrescenta que, nas indústrias têxteis com tecnologia mais avançada, os salários nem sempre são melhores e a rotatividade é considerável 29.

A precariedade das condições e a das relações de trabalho tornam aguda a rotatividade de pessoal. Uma monitora de treinamento em tecelagem comenta: "Hoje, uma moça que se forma para professora não quer ser tecelã. Vai estudando $e$ a indústria vai perdendo as pessoas. (...) $A$ dificuldade é aceitar a função como operária. As condições de trabalho não favorecem. Preferem - escritório, mesmo que ganhem menos. Dá mais status, não trabalham sábado e nem domingo. Aqui na fábrica, elas chegam hoje $e$ já querem sair daqui a um mês".

Há no discurso dos operários queixas sobre a intensidade de ritmo e a ausência de perspectivas, embora também admirem as inovações tecnológicas. Mas, sem dúvida, a carga de emoção e densidade de conteúdo é maior quando se referem às dificuldades. Vejamos suas falas:

"As máquinas novas dão mais produção. Facilitam o serviço. Sempre quem ganha o prêmio de produção é quem toca a máquina nova." (Bobinadeira)

"Repetitivo? Muito. Triste? - Já acostumei com a rotina. A rotina já não incomoda muito." (Fiandeira)
"Acho o trabalho monótono. Ele é repetitivo demais. Ficar limpando, limpando. Vou aprendendo outros serviços para variar. Aprendi a trocar 'viajante' assim, por conta própria. Aprendi sozinha a emendar, na fiação, e a mudar canelas vazias pelas cheias." (Manutencionista)

"Às vezes, as pessoas têm um potencial bom, mas não há tempo de progredir. Eu batalho tanto lá fora, não é justo ficar sempre no trabalho que näo me melhora. Nem como pessoa, nem como profissional." (Operária de Fiação)

"Tem hora que folga bastante, tem hora que não. Precisando de ir ao banheiro, eu vou, a máquina roda como quiser. Quando estou de saco cheio, eu saio mesmo e deixo a máquina. Mesmo se tem dois no banheiro." (Operador)

"Todo mundo gosta de máquinas novas. Diminui o nosso trabalho. É dificil aprender, mas depois é mais fácil." (Operário de Fiação)

"O trabalho é muito repetido; é muito quente; é ruim. Mas preciso deste trabalho." (Operário de Acabamento)

"Cansa muito ficar em pé o tempo todo. Venço o horário cansadíssimo. Dá irritação $e$ nervoso. Se a máquina está rodando normal $e$ de repente estraga o pano, fico nervoso". (Operador de Máquina de Alvejamento)

De fato, não conseguimos extrair das entrevistas com operários demonstrações de maior entusiasmo pelas novas tecnologias e nem de receio, mas queixas diversas sobre a repetitividade, o ritmo, a ausência de perspectiva e o sentido de responsabilidade - já que a remuneração é medida pela produção obtida.

$O$ trabalhador da indústria têxtil mineira praticamente não reflete sobre os impactos sociais possíveis a partir das inovações tecnológicas. Os seus sindicatos são pouco atuantes e as reivindicações restringem-se às questões salariais. Em algumas entrevistas, fala-se vagamente sobre a possibilidade de desemprego tecnológico, mas não há referências aos impactos sobre a qualifi-

26. Referimo-nos, particularmente, às empresas por nós pesquisadas, conforme esclarecimento na nota $n^{2} 19$.

27. SCHMITZ, H.A. "A Microeletrônica: suas implicações sobre o emprego e o salário." Op. cit.

28. Comentário nosso.

29. SCHMITZ,H.A. "A Microeletrônica: suas implicaçóes sobre o emprego e o salário". Op.cit. 
cação, estes capazes de afetar bastante as relações de força vigentes.

Nas fábricas pesquisadas, verificou-se que às inovações tecnológicas tem correspondido uma expansão das instalações e capacidade real de produção. Embora possa ter ocorrido um decréscimo relativo da necessidade de trabalhadores, o movimento ocorreu de forma lenta, ao longo dos anos ${ }^{30}$, sem se caracterizar por momentos de demissão maciça. Há registros de uma política de remanejamento interno, face a compra de novos equipamentos. É importante analisar-se a prática do remanejamento, pois ela significa uma alteração no perfil de qualificação; uma alteração no quadro de requisitos de saberes até então exigidos, o que pode incidir sobre o quadro de forças de mão-de-obra empregada.

Quando citamos os trechos das entrevistas dos operários, observamos as queixas extremamente localizadas no trabalho em si. Por trás destas queixas do indivíduo/trabalhador, está sempre a perspectiva - mesmo que remota de abandonar aquele trabalho, mudar de emprego etc. Há pouca preocupação do sujeito com a situação do trabalho coletivo, entretanto, esta preocupação seria justificada, pois há estudos que refletem a mudança no perfil do trabalho na indústria têxtil face às novas tecnologias.

Percebe-se como, ao avançar no processo de inovação técnica em busca do aumento de produtividade, o capital orientou a tecnologia no sentido de eliminar os postos de trabalho estratégicos, onde a dependência da produção aos trabalhadores era maior. Neste caso, a tecnologia se desenvolveu de modo a eliminar aquilo que no diagnóstico dos engenheiros de produção seriam "os pontos de estrangulamento", tornando os fluxos de produção mais contínuos e prolongados ${ }^{31}$.

Vale a pena examinar o quadro 4, desenvolvido por Schmitz ${ }^{32}$, juntamente com engenheiros do CETIQT, refletindo as diferentes taxas de redução do número de trabalhadores por categoria, no espaço dos últimos 30 anos.

\section{QUADRO 4}

\begin{tabular}{|l|r|r|}
\hline \multirow{2}{*}{ Categoria Ocupacional } & \multicolumn{2}{|c|}{$\begin{array}{c}\text { \% dotal da Força } \\
\text { de trabalho }\end{array}$} \\
\cline { 2 - 3 } & 1950 & 1980 \\
\hline Técnicos e gerentes & 22 & 7,2 \\
Supervisores e instrutores & 2,5 & 6,8 \\
Operador de máquinas & 53,8 & 38,9 \\
Auxiliares de produção & 29,4 & 24,5 \\
Trabalhadores de Manutençäọ & 12,1 & 22,6 \\
\hline
\end{tabular}

FONTE: CARVALHO, 1987, p. 54.
O que se observa neste quadro é uma reconfiguração das categorias de trabalhadores, o que incide, fatalmente, sobre a remodelagem da qualificação social. Triplicaram as hierarquias superiores, que englobam técnicos, supervisores e direção. Dobrou o pessoal de manutenção. Enquanto isso, houve uma queda de cerca de $20 \%$ entre os operadores de máquinas e ajudantes. Há indicações de que parte dos operadores tem se deslocado para a área de manutenção e parte para a categoria de supervisores. Esta tendência, nas indústrias pesquisadas, é confirmada por um dos engenheiros entrevistados: "Os cargos que permanecem mais são os de encarregado $e$ os de manutenção, que foram, antes, admitidos como operadores de máquinas".

O que há de significativo nos remanejamentos é que ocupar um novo posto de trabalho pode implicar em abandono da qualificação anterior e em aquisição de novos saberes. $O$ sujeito trabalhador retorna, então, a uma situação de início do seu processo de qualificaçăo e há, portanto, uma perda no valor de troca em relação ao seu saber fazer.

$\mathrm{Na}$ fase de instalação de novos equipamentos é possível que o valor de troca até aumente. É o que ocorreu, recentemente, com a instalação dos equipamentos de fluxo contínuo no setor de acabamento. Segundo um engenheiro entrevistado, "no setor de acabamento, a pessoa entra sem experiência e aprende aqui. Não se acha, no mercado, pessoal que já tenha experiência".

30. Estudos comparativos, entre as décadas de 50 e 80 , realizados por Schmitz - ver SCHMITZ, H.A. Technology and employment practices in developing countries. Op. cit., p.53 - , revelam "uma reduçāo acentuada da necessidade de mão-de-obra na fábrica; em termos globais, a redução foi de $85,5 \%$ da força de trabalho na fiação $e$ de $80,2 \%$ na tecelagem; a variação por categoria ocupacional é ainda mais significativa, devido a duas consequiências para a composição da força de trabalho: entre os operadores de máquinas, houve uma queda de $83,4 \%$ no pessoal ocupado; entre os auxiliares de produçāo, o declinio foi de $80,9 \%$; no entanto, foi bem menor a redução dos trabalhadores em manutenção $(39,7 \%) e$ dos instrutores $e$ mestres $(36,4 \%)$, enquanto que o número de postos gerenciais e técnicos se manteve virtualmente constante".

31. CARVALHO, Ruy Q. Op. cit., p.55.

32. SCHMITZ, H.A. Technology and employment practices in developing countries. Op. cit. 
Ocorre que, se no início das atividades com um novo equipamento cresce o valor de troca da nova qualificação, a tendência é a uma equalização deste saber em período relativamente curto $e$, conseqüentemente, um retorno à redução no valor de troca daquele saber adquirido. Isto porque a rotatividade é alta e, por outro lado, é muito rápido o período de treinamento.

A política do setor têxtil - caracterizada pela alta rotatividade, poucas qualificaçōes e rígido controle - não é prejudicial apenas para os trabalhadores; ela pode afetar também outros objetivos da própria empresa: é o caso da qualidade do produto. Qualidade é hoje um dos principais objetivos da indústria têxtil brasileira e obtê-la depende de uma mão-de-obra qualificada e experiente, além de tecnologia adequada.

A busca de um produto melhor é explicada quando se observa a posição da indústria nacional face ao contexto mundial. Tauile ${ }^{33}$ analisa a questão da competitividade no setor têxtil enquanto uma necessidade de ganhar fatias do mercado externo consumidor para equilibrar os períodos de crise interna. E, para isso, vai depender da capacidade de produzir tecidos de boa qualidade de baixos custos unitários. Porém, a competitividade só será possível acompanhando-se o padrão de automação microeletrônica em curso nos países desenvolvidos ${ }^{34}$. A perspectiva de adoção da microeletrônica prenuncia um impacto sobre a utilização da força de trabalho. É que a microeletrônica garante a melhor qualidade no produto final em relação à produçãoo de base eletromecânica, além de reduzir os ganhos com os baixos salários até então obtidos pelas indústrias dos países em desenvolvimento ${ }^{35}$.

Se já deixamos explícito que a exportação de tecidos exige um produto de melhor qualidade, devemos agora clarear as implicações que o fator moda possa ter para a organização produtiva da indústria têxtil. As mudanças da moda implicam na constante alteração das fibras utilizadas, das padronagens etc. Isto exige maior flexibilidade na produção, pois afeta a programação dos equipamentos e a habilidade de quem os opera.

Os objetivos de produtividade, qualidade $e$ flexibilidade são melhor atendidos através de equipamentos baseados em tecnologia microeletrônica. Estes equipamentos, por sua vez, exigem uma mão-de-obra mais qualificada - o que é discutido de maneira muito apropriada em trabalhos como os de Carvalho ${ }^{36}$, Schmitz ${ }^{37}$ e Acero ${ }^{38}$. Mas como essa não é a finalidade do presente estudo, porque as empresas pesquisadas não utilizam a microeletrônica, vejamos como elas têm atendido estes mesmos objetivos, através dos equipamentos convencionais, e que implicações trazem estas medidas para a gestão das qualificações da força de trabalho.

A política de alta rotatividade, pouca qualificação e baixos salários é compensada com o reforço no grupo de supervisores e técnicos. Homs ${ }^{39}$ descreve o procedimento, dizendo que o baixo nível de formação do pessoal, sobretudo dos operários, tem contribuído para que a empresa se baseie em encarregados e contramestres para organizar a mudança. O operário fica destinado às funções de vigiar e controlar o equipamento.

Mas, prossegue o autor, "fica a impressão de que existe um acúmulo de responsabilidade à medida em que sobe o escalão hierárquico da empresa. Os problemas não se resolvem onde se produzem, sobem muito facilmente aos niveis superiores". De fato, os problemas de base que não são resolvidos pelos operários passam para os encarregados e técnicos; mas, como, mesmo neste nível hierárquico, são baixas as qualificações, freqüentemente os problemas de base chegam até a gerência ou diretoria.

A autonomia do operário é muito restrita ao desempenho da tarefa rotineira - certamente porque é baixa a sua qualificação. Também os encarregados - não muito mais qualificados restringem suas funções ao controle sobre os

\section{TAUILE, J.R. Op. cit.}

34. A tendência para a adoçăo de equipamentos baseados na microeletrônica pela indústria nacional é praticamente irreversível. Esta inovaçăo incidirá sobre a competitividade a nível internacional e a nível interno. Os estudos do INDI são claros quanto a isso:

"A medida que um grupo de empresas melhor se aparelhe, sua competitividade se eleva também no mercado interno, o que pode contribuir para deslocar indústrias tradicionais".

Comenta, ainda, que outros fatores têm influenciado o mercado têxtil brasileiro, além da modernização tecnológica e da evolução das exportaçōes. Entre os fatores apresentados, destaca-se o "dinamismo da moda". Ver: INSTITUTO DE DESENVOLVIMENTO INDUSTRIAL DE BELO HORIZONTE (INDI). $A$ indústria têxtil de Minas Gerais. Belo Horizonte, dezembro, 1985 .

35. TAUILE, J.R. Op. cit., pp. 52-54.

36. CARVALHO, Ruy Q. Op. cit.

37. SCHMITZ, H.A."A Microeletrônica: suas implicaçðes sobre o emprego e o salário". Op. cit.

38. ACERO, L."Technical change in a newly industrializing country: a case study of the impacts on employment and skills in the brazilian textiles industry, SPRU". Op. cit.

39. HOMS, O. Formacion y cualificacion en el sector de confeccion y textil en España. Madrid, 1986 (mimeo). 
operadores de máquinas, sem participar mais ativamente nos trabalhos de programação, que já vem traçada pela hierarquia superior. $O$ discurso de alguns supervisores reflete bem essa posição.

"Eu domino o fluxo, mas sigo o programa de produção feito pela chefia. O operário não sabe 0 que tem que fazer. O encarregado diz porque tem o programa de produção. Termina uma programação e o encarregado já está pronto para passar a outra. Exemplo: enquanto está estampando, o elemento tem autonomia (é ele que sabe se está certo ou não) dentro do processo de qualidade etc. Mas se era isto ou aquilo que ia ser feito é o encarregado que sabe."

"Eu sou responsável pela qualidade. Tenho que meter o dedinho para dar boa qualidade. E 0 segredo é um bom treinamento $e$ o controle para não deixar o tecelão tocar o tear de qualquer jeito. Eles sabem que, se não fizer direito, na revisão nós acusamos isso. E eu tenho um livrinho preto onde anoto o desempenho dos maus tecelöes. (...) Todo dia eu consulto ele. Foi pro livrinho, eu aperto o sujeito até ele voltar nos eixos."

"Minha função principal é apertar bastante o pessoal. Tem que apertar sem ser carrasco. Apertar sem fazer força. Recorrendo a técnicas do convencimento. Como fazer o tecelão trabalhar da melhor maneira? É uma coisa minha, que eu criei: fazer ele anotar a sua produção num caderninho particular todo dia. No final do mês, ele confere com o seu salário. Se tá certo e ele tá insatisfeito com o dinheiro, ele só tem uma saída: produzir mais. Assim, ele mesmo se aperta, se exige."

Transparece nestes trechos de entrevista que os objetivos da produção são obtidos mediante rígido controle. Mas o excesso de controle pode prejudicar o envolvimento do operário com o produto, e este envolvimento é vital para que se obtenha um resultado de melhor qualidade. Um engenheiro entrevistado explicita bem esta necessidade: "Até 1966 nāo se falava, aqui, em qualidade. Com a mudança de mercado, passouse a atender uma fatia mais exigente. Tivemos que investir também em mão-de-obra. Há necessidade de se conscientizar em relação à qualidade, de haver relacionamento do operário com - produto. $O$ conteúdo das atividades mudou muito. Há mais participação do empregado, ele sabe o que está produzindo e o porquê. Fizemos um trabalho de conscientização."

Neste depoimento, fala-se em conscientização e, em outros, a estratégia de obtenção de qualidade resume-se ao controle.

"A necessidade de um tecido melhor deixa todos mais atentos. Passamos a controlar. Controla-se porque uma peça de 100 metros só pode ter dez defeitos, que é o padrão internacional." (Engenheiro)

Em síntese, a preocupação com as exigências dos padrões internacionais já é uma constante, mas, por outro lado, é uma preocupação recente. Observamos, de outro lado, que a definição de gestão da mão-de-obra para obtenção destes padrões ainda não é claramente definida.

Conforme será visto na próxima seção, uma melhor qualificação da mão-de-obra depende muito do nível de experiência do sujeito-trabalhador, o que entra em contradição com uma política de alta rotatividade de pessoal. Neste sentido, uma estabilidade maior nas relações de trabalho seria a estratégia mais adequada para obtenção de uma força de trabalho estável, experiente $e$, conseqüentemente, mais qualificada. Para isso são indispensáveis mais profissionalização e melhores condiçðes de trabalho, conforme os depoimentos de dois supervisores:

"Mão-de-obra especializada não existe. Tem que ter um treinamento, preparação do profissional. $O$ salário é baixo. O horário de trabalho dificil. A mão-de-obra é mais rebelde, mais instável, o pessoal é mais fácil de ser influenciado pelos líderes negativos. $E$ uma dificuldade nacional; o setor tem que dar uma reviravolta: melhorar o salário $e$ as condições de trabalho que são muito ruins."

"Na medida em que se profissionaliza, a vigília sobre o empregado diminui."

\section{SABER FAZER: A QUALIFICAÇÃO TÁCITA}

As inovações tecnológicas constantes e o dinamismo característico da moderna sociedade industrial tornam evidentes os efeitos indesejados do taylorismo. "A um certo nivel de parcelamento do trabalho, os setores de método já não são mais capazes de assegurar a função de coleta $e$ de coordenação das informações necessárias ao controle dos processos de produção" 40.

A incapacidade de coletar estas informações é decorrente da existência de um nível de conhecimento sobre o desenvolvimento das tarefas, que só o próprio executor adquiriu. A aquisição deste conhecimento se dá no processo de vivência com a produção e com a tarefa específica executada. Mas, uma vez adquirido, dificilmente é transferível. Trata-se mais de uma "apreensão" do que de um conhecimento e, por isso, é prati-

40. CHANARON, J.J. e PERRIN, J. "Science, technologie et modes d'organization du travail":. In: Sociologie du travail. Paris, $n^{2} 1,1986$, p.33. 
camente impossível de ser codificada. A esta "apreensão" é que se chama "saber fazer", indispensável ao desenvolvimento eficiente dos processos produtivos.

As discussões sobre o saber fazer aparecem em vários autores, algumas vezes com nomes diferentes, permanecendo o mesmo conceito básico. Para Tersac e Coriat o saber fazer é um saber complementar, incorporado ao dispositivo técnico, mas indispensável, pois sem ele o sistema técnico não pode funcionar. Trata-se de um subproduto do sistema técnico, que passa a uma condição primeira de sua eficácia e de seu funcionamento ${ }^{41}$.

Jones e Wood 42 referem-se ao "conhecimento tácito", como aquele apreendido através da experiência individual; ele é difícil - quase impossível - de se exprimir dentro de uma linguagem explícita e formalizada, e está ligado, geralmente, a uma situação específica. A simples memorização de uma série de instruções detalhadas será insuficiente para garantir o cumprimento da tarefa. Para Chanaron e Perrin, mesmo que uma parte do saber fazer seja transferida para a "lógica" de uma nova máquina, os trabalhadores precisam criar novos saberes para fazêla funcionar ${ }^{43}$.

As qualificações tácitas são vitais para a compreensão do processo produtivo. Desenvolvidas pelos trabalhadores especializados, mas desconhecidas da gerência, fornecem a esta gerência o feed-back sobre o funcionamento dos procedimentos implantados. Essas contribuições, que são cruciais, não são bem articuladas ao nível da organização formal. Entretanto, para o pessoal da direção e supervisão de uma empresa, desconhecer as qualificaçőes tácitas significa não tomar conhecimento total da maneira como as diferentes funçōes são cumpridas no seio da organização.

O modo de fazer operário é desenvolvido e repassado no processo de cooperação e. convivência em equipe, por isso os sistemas de códigos criados pelo universo de cada grupo e a partir de cada grupo são básicos para a aquisição e transferência do saber fazer.

A especialização, em função do trabalho executado, é que estabelece as diferenças formais ou informais nos códigos, linguagens e símbolos utilizados pelos diversos grupos de trabalhadores. Por exemplo, os engenheiros podem resumir um projeto ou um processo de maneira mais completa que os outros grupos de trabalhadores, porque dominam conceitos e termos abstratos e formalizados. Mas sua forma de representação do real não foi apreendida no contato com a experiência da produção, sua com- preensão do processo não é tão direta como é a do operário. Nesta medida, as qualificações tácitas do trabalhador de oficina funcionam como fontes de informações essenciais e complementares sobre a organização do trabalho.

Além de permitir um conhecimento mais próximo do real, o saber fazer otimiza a relação do trabalhador com as próprias máquinas. $O$ saber fazer permite (através de sinais informais) a gestão de zonas de incerteza nascidas das perturbaçōes, o que possibilita antecipar as panes e prever as conseqüencias de um desvio de uma rota de produção. Na prevenção de estados indesejados, o desenvolvimento das percepçбes captadas através dos sentidos (olfato, visão, audição, tato) é extremamente importante, pois dali se percebe o início das condiçōes imprevistas. A capacidade de apreender essas espécies de fenômenos é que se adquire pela vivência.

Por outro lado, a detecção de estados anormais não depende exclusivamente do uso dos sentidos. Prever panes, estabilizar processos, otimizar a realização de manobras excepcionais são procedimentos que dependem de processos mentais complexos, baseados na análise da atividade real.

$\mathrm{Na}$ indústria têxtil, a prevenção dos "incidentes" que danificam o tecido afetam tanto os objetivos de qualidade da empresa quanto os objetivos do empregado, que ganha por produção. Por isso, é vital ao "tecelão" o uso do sentidos, a prevenção de estados indesejáveis, o cuidado no trabalho, a aprendizagem com o outro, a cooperação no trabalho, o "jeito", agilidade, atenção, cuidado com a máquina, habilidades manuais ou de raciocínio - a depender do posto de trabalho. Alguns dos depoimentos recolhidos dão a dimensão do saber fazer. Vale a pena reproduzir o discurso de uma monitora de treinamento, com 30 anos de vivência em tecelagem, dissecando o que fazem as tecelãs e suas ajudantes, e as "qualidades" exigidas para estes dois postos:

"O trabalho da tecela é operar 50 teares. Se o tear pára, ela faz rutura e continua patrulhando. $A$ responsabilidade da produção é dela. O trabatho da ajudante é auxiliar a tecelã: passa a esbarrada, demanda defeito, marca o pano, liga e desliga, procura a ponta da linha. Ela ajuda mais ou menos 80 teares. Mas a tecelã é que é responsá-

41. TERSAC, G. e CORIAT, B. "Micro-électronique et travail ouvrier dans les industries de process". In: Sociologie du travail. Paris, $\mathrm{n}^{2} 4,1984$, p.388.

42. JONES, B. e WOOD, S. "Qualifications tacites, division du travail et nouvelles tecnologies". In: Sociologie du travail. Paris, $\mathrm{n}^{\circ} 4,1984$, p.411.

43. CHANARON, J.J. e PERRIN, J.Op. cit., p. 36. 
vel pelo trabalho. $A$ ajudante ganha mais ou menos sobre o salário da tecelã. Mas a tecelã ganha mais. Para ser uma ótima tecela, tem que ter qualidade, ambição, cuidado com a máquina, "carinho" com a máquina que a gente trabalha - a máquina é emprestada. Uma aprendiz porca, que suja o pavio, não liga para o que produz $e$ quanto ganha, não será uma boa tecelă. O treinamento na escolinha funciona com a máquina quase parada, lá na seção o tear não pára. Lá, o pano tem mais defeitos, tem muita malha estragada, porque o tear quebra a malha. $A$ ajudante nunca que satisfaz uma tecela. Toda tecelã põe defeito na ajudante, porque é lenta, não é caprichosa. A tecelä não dá muito valor à ajudante. Agora, subir de ajudante para tecelã é uma promoção.

$A$ ajudante tem que ser melhor que a tecela, porque a esbarrada é muito dificil. Esbarrada é quando a lançadeira se enrola na espula (linha da trama); ai arrebenta um monte de fio e quem conserta é a ajudante. É preciso ter um 'jeito' para ser teceläo? $O$ jeito da pessoa ajuda. Tem pessoas que no teste você vê que não dá. Tem que ter queda. No teste, se não passar hoje, tenta de novo. Pode ser que esteja nervosa da primeira vez. Mas a gente tem que saber se a pessoa tem jeito ou não. Tem que dar um tempo para a pessoa melhorar. A gente também leva o candidato na seção, para ver se o barulho incomoda demais, se o cansaço é grande demais. Quando volta da seção, eu pergunto: 'gostou?'. Uns dizem: 'eu nao volto'. Outros: 'eu gosto $e$ vou voltar'. Volta à seção quantas vezes for preciso, até ter certeza se a pessoa tem jeito ou näo."

Deste depoimento extraem-se, basicamente, a necessidade de atenção; cuidado com a máquina; a capacidade de suportar as condições do ambiente - barulho, pó etc.; o "jeito"; agilidade; habilidades manuais; cooperação; aprender com o outro; um sistema próprio de códigos e um conhecimento acumulado.

A cooperação no trabalho - citado por Jones e Wood também como característica do saber fazer - é reforçada pelo depoimento de uma operária da fiação: "A quantidade e qualidade do seu produto depende de outros colegas. Depende das outras que rodam a mesma máquina que eu, em outro horário." (Fiandeira)

A agilidade é também necessária, inclusive para a proteção do próprio operário, pois evita as panes do processo ou os acidentes de trabalho: "Tem que ser rápido na observação; se passar muito tempo, é muito pano estragado". (Estampador)

"O operário precisa ser mais ágil, mais esperto. Todo o processo é agora mais rápido." (Su- pervisor)

"Sempre fui muito cuidadosa. E também dei sorte. Era muito comum uma espuladeira passar voando por mim, mas nunca acertou." (Monitor de Tecelagem)

Os monitores de treinamento, sempre antigos operários da produção, com larga experiência, tentam repassar aos novatos a teoria e a sua prática. A vivência é importante no setor têxtil assim como o envolvimento.

"No treinamento, dou aula prática e teórica. Tenho que ensinar a pessoa, não só a fazer o tecido mas a ser uma boa produtora. Um tecelāo que dê produção e qualidade." (Monitor de Treinamento)

"As novatas deixam arrebentar muito cadarço na virada. Elas deixam passar defeito. $A$ gente tem que ficar olhando. Tem umas que têm boa vontade de aprender." (Fiandeira)

A atenção e a capacidade de se ajustar a novas exigências são também requisitos importantes, principalmente quando se leva em conta os objetivos de qualidade e flexibilidade.

"Por aqui passam todos os panos crus. A pressão da balança pode variar, as chamas de fogo também não são iguais para cada pano: algodão, poliéster, viscose etc. Você tem que estar atento para isso." (Operador de Chamuscadeira)

"Meu trabalho na fiação não depende da quantidade de rolos de fio produzidos. A quantidade de rolos para eu fiar vai depender do tipo de tecido que é produzido. Não posso deixar o fio passar embaraçado, tenho que contar os fios que passam nos pentes. E preciso muita atenção." (Fiandeira)

$\mathrm{Na}$ fiação e na tecelagem, onde o trabalho implica habilidade manual, o saber fazer está mais relacionado à atenção e agilidade. Já nos equipamentos de fluxo contínuo, no setor de acabamento e preparação de fios, o trabalho depende também de conhecimentos da máquina e capacidade de abstração para lidar com a representação simbólica dos painéis; por isso o seu saber fazer implica em acuidade e raciocínio, além de ser necessário um maior nivel de escolaridade.

"No alvejamento continuo, a mão-de-obra precisa de mais raciocínio. O operador, além de se preocupar com o painel da máquina, sincronia da máquina, capacidade, velocidade, observa também o grau de beneficiamento do pano. Para sair um 'bom pano', o operador controla a velocidade, entrada do tecido no 'castelo', o passamento dos abridores, volume de pano na vaporização, nível de banho nas caixas, grau de branco na saída, secagem de pano na saida. Tudo é controlado pelo operador. Cada máquina tem três operários: um preparador de banho, um 
operador, um auxiliar de operador. $O$ nivel de qualificação dos três é igual, exige-se $1^{9}$ grau completo." (Operador de Alvejamento Contínuo)

"O alvejamento convencional absorvia 25 funcionários por turno, a nivel de operação; podiam ser até analfabetos $e o$ treinamento $d u$ rava dois dias. No alvejamento contínuo, são três operadores de máquina por turno e exige-se conhecimento de máquina grande, a nivel de qualificação. A formação é de seis meses a um ano. $\dot{E}$ preciso ter sensibilidade, acuidade $e$ conhecer a máquina a fundo. Sempre exige-se que o encarregado tenha qualificação de nivel técnico. A nivel de operação, usa-se o pessoal antigo. "(Engenheiro)

A discussão sobre o saber fazer ganha espaço quando se percebe que ali reside uma dimensão irredutível da qualificação. Sua aquisição vem da prática, vivência e experiência, o que nos leva a crer que dificilmente poderia ser adquirido em rápidos processos de treinamento. Podese mesmo dizer que este saber fazer reside no tempo de convivência do operário com o processo, já que sua qualificação vai além dos níveis de escolaridade e dos conhecimentos técnicos específicos. Por esta razão, as gestðes de recursos humanos que se baseiam na alta rotatividade acabam por cair num procedimento desqualificante e questionável, inclusive para a própria eficiência da produção.

"Oito horas lá, dando nó, ligando a máquina. Você faz aquilo até de olho fechado." (Tecelã) Fechar os olhos é sempre um risco.

\section{CONSIDERAÇÕES FINAIS}

Nosso objetivo neste estudo foi levantar alguns aspectos do tema qualificação, considerando sua importância para a área de gestão da força de trabalho. Do nosso ponto de vista, trata-se de um tema mal estudado e não suficientemente levado em consideração na busca de gerenciar recursos humanos.

Foi o que constatamos no decorrer da pesquisa, e que pode ser exemplificado através da am- bigüidade que se percebe entre a idéia de qualificação e o uso das tecnologias, traduzido em termos de objetivos conflitantes. De um lado, são inexoráveis o avanço tecnológico e a busca de padrões de qualidade e flexibilidade da produção visando a um maior desempenho competitivo pela indústria nacional. De outro lado, esta mesma indústria vem se apoiando numa gestão de força de trabalho, voltada para uma prática de intensa rotatividade da mão-de-obra, que desqualifica o trabalho coletivo.

É contraditório observar no discurso de supervisores e técnicos a preocupação com a necessidade de maior qualificação, para atender aos parâmetros internacionais de qualidade vis-àvis com sua prática de RH. É verdade que esta exigência é recente, e não sabemos como esta ambigüidade será resolvida no futuro.

Mas é possível que o reconhecimento do saber fazer, como prática intransferível e vital para o funcionamento do processo produtivo, acabe motivando uma política calcada na confiança sobre o trabalho operário, o que deve ser desdobrado em melhores condições de trabalho e maior estabilidade do emprego. Dois pontos, no entanto, gostaríamos de salientar, ao se tentar fazer as consideraçôes finais sobre o estudo da qualificação:

O que distingue um determinado campo de análise e decide sobre sua evolução são os diferentes modos de questionamento da realidade social acrescidos da evolução perceptiva do objeto alvo da análise. A possibilidade de formalização de uma realidade/prática social não passa tanto pela adição de conhecimentos parciais mas pela formação de novos objetivos de análise que se interligam.

- Finalmente, a análise da estrutura da organização profissional ou do sistema de qualificação passa por variáveis diferentes. No entanto, a mais importante é a variável que trata do acesso ao sistema ${ }^{44}$. É em torno dela que se deve centrar a análise da qualificação.

\section{REYNAUD, J.D. Op. cit.}

ABSTRACT: The object of this paper is to discuss some aspects of the concept of skill, the analysis of which is based upon observed work relations in some textile mills in Minas Gerais, Brazil. One notices some hesitation in embracing the idea of qualification and adopting new technology in the industry. Rational policies based on high turnover rates, low skills and low wage rates have been used as a means of control over the labor class. But they also imply poor quality of the final product which remains below the external market requirements, thus reducing competitive power.

Because some aspects of skill and know how can not be easily codified or transferred to newcomers, they require a long period of practice living close to the production line.

KEY WORDS: Labor relations, work relations, skill, know how, technology. 